\title{
Analysis of Shaanxi Folk Music Teaching Method Based on New Media
}

\author{
Qianwen Song \\ Xianyang Normal University, Musical Department, Xianyang, Shaanxi, China 712000
}

Keywords: New media; Shaanxi folk music; Teaching method

\begin{abstract}
Since the implementation of the "Internet Power Strategy ", China's Internet system has become increasingly sound. The Internet has begun to enter every corner of our work and life. The Internet and new media have outstanding communication advantages. The healthy promotion of China's higher education is inseparable from the powerful wings of the Internet and new media. Optimizing the teaching system and effectively improving the quality of teaching with the help of network resources and IT technology is the tendency of future development of education and teaching. The integration of folk music teaching in Shaanxi with the Internet and new media is also imperative. This paper analyzes the teaching methods of folk music based on new media in Shaanxi in order to provide a basis for improving the quality of folk music teaching in Shaanxi.
\end{abstract}

New media mainly refers to high-tech technologies such as application networks (communication and exchange), computers (computing and information processing), and media that innovate traditional media content, forms, and types. New media forms include art design, human-machine interface, industry differentiation and multimedia. The combination of new media and the Internet effectively solves the problem of real-time information transmission, breaking the constraints of time and space on information transmission. At the same time, new media is spread in a variety of forms, through which the information can be presented in the form of video, images and the like. The combination of the Internet and new media has revolutionized many areas. At present, the fields of media, technology, education and enterprises have become the frontiers of new media applications. New media has a natural combination with education and teaching. In the education and teaching, new media can give full play to the effectiveness of multimedia to enrich the teaching content, improve the expression of education and teaching, optimize the education and teaching system, and thus achieve the purpose of improving teaching quality. In the field of folk music teaching in Shaanxi, due to historical and cognitive reasons, the application of new media in the field of education and teaching is still not very common, and the matching educational and teaching achievements are also very weak. How to apply new media in Shaanxi folk music teaching is still at a relatively preliminary stage. According to the author's research, giving full play to the characteristics of new media is a key node in the transformation of Shaanxi folk music teaching methods. In recent years, many educators have made some useful attempts on this issue and have achieved certain results. However, how to combine the new media with the teaching of folk music in Shaanxi so that the two promote each other, complement each other is still a new topic until now. The author believes that the reform of Shaanxi folk music teaching methods based on new media should focus on the following aspects:

\section{Create Shaanxi folk music teaching conditions based on new media}

Compared with other teaching methods, new media teaching requires certain teaching conditions. Firstly, new media teaching requires specific multimedia teaching equipment. The teaching equipment is the prerequisite hardware conditions for education and teaching, including high-performance computers, projectors, and slide projectors and so on. Due to factors such as lacking of funding, many colleges and universities haven't completed the systematic construction of multimedia teaching equipment, especially non-985, non-211 colleges. In recent years, the investment of colleges and universities in this area has been significantly strengthened, and the hardware constraints that constrain the application of new media teaching have been gradually 
solved. Secondly, because the educational resources related to Shaanxi folk music haven't been integrated before, especially the multimedia teaching and teaching resources are relatively scarce and how to establish the educational and teaching resources of Shaanxi folk music in a scientific and orderly manner is an urgent problem to be solved. Many teachers who are engaged in the teaching of folk music in Shaanxi are born in liberal arts. Their experience in producing multimedia information is obviously insufficient compared with science and engineering teachers. Many teachers have low computer levels, which restricts the development of related work to a certain extent. In response to this problem, the school should do its job, play a good organizational leadership role, and fully mobilize all the resources that can be coordinated to do the integration and development of Shaanxi folk music education and teaching multimedia resources, so that the Shaanxi folk music multimedia course system can comprehensively spread out. Finally, the majority of teachers should thoroughly change the traditional concept of education and teaching, actively learn the techniques of new media teaching, be good at using Internet equipment, be good at integrating various teaching methods, optimize education and teaching ideas, and strive to provide suggestions in integrating organic media with Shaanxi folk music teaching, laying a solid foundation for better development of new media teaching.

\section{Create a teaching atmosphere of Shaanxi folk music based on new media}

A good teaching atmosphere is a prerequisite for effective implementation of teaching objectives. A good atmosphere is conducive to mobilizing the enthusiasm, initiative and creativity of teachers' teaching practice, which is conducive to the purpose of improving the quality of Shaanxi folk music teaching. To build a good Shaanxi folk music teaching atmosphere based on new media, the following aspects are needed: Firstly, reform the education system. When adding new media classes in the regular teaching system, teachers are encouraged to apply new media to practice teaching, so that they can accumulate new media teaching experience in teaching practice. Schools should guide teachers to establish awareness of new media teaching and improve teachers' teaching methods enlightenment; secondly, do a good job in the reform of the teaching evaluation system. Establishing the teaching standards of Shaanxi folk music teaching methods based on new media and qualitatively analyzing the effectiveness of new media teaching methods, so that teachers can clarify the advantages and disadvantages of new media education and teaching, pointing out the direction for their innovation and improvement of teaching methods, and promoting the positive development of new media teaching cause; in the end, perfect the performance appraisal system. Incorporate the practical results of teaching methods based on new media into the teacher performance appraisal system, help teachers to apply new media to carry out teaching practice activities, mobilize the enthusiasm of teachers to use new media for teaching innovation and teaching reform, and build a good new media practice atmosphere and therefore, the new media teaching method will be widely implemented in the Shaanxi folk music education system in the future.

\section{Clear the teaching objectives of Shaanxi folk music based on new media}

Education aims to guide teachers to integrate education resources and optimize the "core strength" of education methods. Only when education objectives are objective, scientific and feasible can we standardize the reasonable application of new media by teachers. In the context of quality education, the ultimate goal of our education and teaching is to effectively improve the overall quality of students. The drawbacks in traditional education and teaching have seriously hindered the achievement of the goal of higher education in China in the new era. As the main part of education and teaching, students have a strong sense of participation and cognition for new things. New media teaching can give students a full sense of participation. At the same time, new media teaching has an alternative role in arousing students' enthusiasm and creativity. We must change the past cramming education and teaching methods, adjust the target of education and teaching to serve students, shape students and lead students. Teachers should pay more attention to 
improving students' interest in learning, learning ability and innovative thinking. Try to teach students in accordance with their aptitude and fully publicize their personal talents. Shaanxi folk music teaching based on new media should focus on breaking the high marks but low capacity talent training pattern. Instead, it is the first priority to improve quality education. We should make sure that students truly understand Shaanxi folk music, know its past, familiar with its present, and then portray its future. Let students consciously establish a sense of protecting national music.

\section{Do a good job of top-level design of Shaanxi folk music teaching based on new media}

Teaching top-level design mainly refers to the macroscopic perspective, insight into the development direction of education, and grasp the overall practice of education. Through pre-design, the quality of teaching is guaranteed and the teaching method is scientific and feasible. The top-level design of Shaanxi folk music teaching based on new media mainly includes two parts: theory and teaching practice. In theory, teachers should explain to students the theoretical development of Shaanxi folk music, artistic characteristics, music expression, singing and performance points, etc., so that students have a general and clear understanding of Shaanxi folk music and form a deep understanding of Shaanxi folk music basic judgment and cognition. For example, teachers can use the multimedia equipment to play the folk music performances of Zhenba folk songs, Ziyang folk songs, Hundreds Birds Worshipping the Phoenix and other Shaanxi folk music before the start of classroom teaching, to infiltrate the music knowledge into videos, pictures, text cases, and audio. Through enriching the versatile forms of knowledge expression, mobilize the enthusiasm of students to learn independently, stimulate students' interest in learning, guide students to actively appreciate, analyze and understand relevant works, and lead students' thinking with Shaanxi folk music knowledge, to actively build teacher-student interaction. The teaching atmosphere makes music knowledge come from the discussion of students rather than the rigid traditional teaching, which makes teaching discussion become the link connecting teachers and students and deepen students' understanding of Shaanxi folk music art form. In teaching practice, we must also fully integrate into the form of new media. For example, when teaching a student to play a folk instrument in Shaanxi, the tupans, drums, cymbals, etc., the teachers can make the musical instrument playing steps into comics, pictures or small videos, play them out with new media equipment, guide the students to analyze, figure, and practice independently, and the teacher plays the role of the leader and through observation, teachers will guide and standardize the students' playing methods, and give students a targeted teaching explanation. For students' difficult music learning difficulties, teachers can use the new media to collect relevant performance videos for students to understand from various levels, master relevant performance techniques, and implement Shaanxi folk music teaching goals in a subtle way. In the practical training of teaching, we should also give full play to the educational and teaching role of new media. Music teaching especially focuses on practical training, and Shaanxi folk music teaching is no exception. After mastering a certain singing and playing skills, students generally need to strengthen them through performances. Teachers can make the student's performance process into new media materials. These materials can be used as teaching resources and can also be used as materials for class discussion. Students can see each other's shortcomings by watching these performances and objectively analyze the advantages and disadvantages of performance. The new media has also broken the traditional training methods. In the context of new media, the development of training courses is no longer limited by time and place. Live video, web conferencing, etc. can allow students and teachers to communicate anytime and anywhere. This new media interaction platform has been widely used in many fields. As far as its practical application results are concerned, it is incomparable to the traditional training system. The curriculum system of micro lecture, MOOCs, and flipped class model has been greatly developed in foreign countries. At present, many colleges and universities in China have been committed to combining their own schools to create their own excellent courses based on new media. Shaanxi folk music teaching should carry out active and bold exploration in these aspects rather than stand still, always wandering in the traditional education teaching system. 
The education and teaching methods based on new media in China started late compared with the developed countries in the west. In many aspects, the teaching experience is relatively scarce and the research foundation is relatively weak. However, after years of unremitting efforts by the vast number of educators, we have made great achievements in many aspects. We should base ourselves on the teaching of folk music in Shaanxi, continue to accumulate new media teaching experience from the practice of education and teaching, constantly optimize the teaching and learning system and give full play to the advantages of new media music teaching.

\section{Conclusion}

Shaanxi folk music has a profound historical foundation. The Shaanxi folk music art, which has been handed down from before Common Era to now, is a shining pearl in the crown of folk music and a classic art form worth further study and inheritance. As a folk music teaching worker in Shaanxi, in the future teaching, I will base on the new normal of folk music teaching in the new era, strive to create the teaching conditions of Shaanxi folk music based on new media for students, create a teaching atmosphere of Shaanxi folk music based on new media, fully implement the teaching objectives of Shaanxi folk music based on new media, do a good job of top-level design of Shaanxi folk music teaching based on new media, give full play to the advantages of new media teaching and help the steady development of Shaanxi folk music education and teaching.

\section{References}

[1] Qiao Wenqing. On the Development Trend of Music Course Teaching Under the Background of New Media [J]. Times Report, 2018 (18): 248.

[2] Wang Huiying. Analysis of College Music Teaching Reform in the Age of New Media [J]. Northern Music, 2018(14): 129-130.

[3] Huang Xiaoyin. On the Music Teaching in the New Media Era [J]. Information Construction, 2015(12): 177.

[4] Zhang Ning. Research on the Reform Strategy of College Music Teaching under the Perspective of New Media [J].Journal of Hebei North University (Social Science Edition), 2017(5):104-106.

[5] An Yongming. The Path Choice of the Transformation of Music Teaching Mode in the New Media Environment [J]. Science and Technology Journal - Electronic Edition (early), 2018 (7): 85, 87.

[6] Li Wenhong. An Analysis of the Artistic Characteristics of Music Education in Colleges and Universities--A Case Study of Quality Education [J]. Heilongjiang Researches on Higher Education, 2017, (01):171-173

[7]Wang Jiaqi. Research on the Reform and Development Countermeasures of School Music Education in China [J]. Drama House, 2017, (03): 195-196

[8]Chen Pu. Problems and Countermeasures of the Connection between Music Education Major and Basic Music Education in Colleges and Universities [J]. Shanghai Education Research, 2017, (01): 71-72

[9]Wei Min. Research on Music Education in Higher Vocational Colleges from the Perspective of Quality Education [J]. Health Vocational Education, 2017, 35(10): 19-20. 